\title{
Fate of recombinant DNA and Cry1Ab protein after ingestion and dispersal of genetically modified maize in comparison to rapeseed by fallow deer (Dama dama)
}

\author{
P. Guertler • B. Lutz $\cdot$ R. Kuehn • H. H. D. Meyer • \\ R. Einspanier • B. Killermann • C. Albrecht
}

Received: 8 February 2007 /Revised: 11 April 2007 / Accepted: 11 April 2007 / Published online: 4 May 2007

(C) Springer-Verlag 2007

\begin{abstract}
The fate of recombinant DNA in fallow deer (Dama dama) was investigated by feeding a diet of isogenic or genetically modified (GM) maize expressing $\mathrm{Cry} 1 \mathrm{Ab}$ protein against the European corn borer (Ostrinia nubilalis). To study the degradability of ingested DNA, polymerase chain reaction (PCR) assays were introduced to detect fragments of the endogenous, highly abundant chloroplast-specific rubisco gene, the maize-specific zein gene and the recombinant $c r y l A b$ gene. PCR analysis revealed that small chloroplast- and maize-specific DNA
\end{abstract}

Communicated by W. Lutz

P. Guertler · B. Lutz · H. H. D. Meyer · C. Albrecht

Physiology Weihenstephan, Technical University Munich,

Weihenstephaner Berg 3,

85354 Freising, Germany

\section{R. Kuehn}

Wildlife Biology and Wildlife Management Unit,

Technical University Munich,

Am Hochanger 13,

85354 Freising, Germany

R. Einspanier

Institute of Veterinary Biochemistry, Freie Universität Berlin,

Oertzenweg 19b,

14163 Berlin, Germany

\section{B. Killermann}

Institute for Crop Science and Plant Breeding,

Bavarian State Research Center for Agriculture,

Lange Point 6,

85354 Freising, Germany

C. Albrecht $(\bowtie)$

Institute of Biochemistry and Molecular Medicine,

University of Bern,

Buehlstr. 28,

CH-3012 Bern, Switzerland

e-mail: christiane.albrecht@mci.unibe.ch fragments were detectable in contents of rumen, abomasums, jejunum, caecum and colon and occasionally in visceral tissues. In contrast, no fragments of the recombinant $\operatorname{cry} 1 \mathrm{Ab}$ gene were detectable in gastrointestinal (GI) contents. The Cry $1 \mathrm{Ab}$ protein was analysed using an enzyme-linked immunosorbent assay (ELISA) and immunoblotting technique. Neither ELISA nor immunoblotting yielded positive signals of immunoactive Cryl $\mathrm{Ab}$ protein in GI contents and tissues of fallow deer fed with GM maize. In conclusion, after uptake of GM maize, neither $c r y 1 \mathrm{Ab}$ specific gene fragments nor Cryl Ab protein were detected in the GI tract of fallow deer, indicating complete digestion of the GM maize. Additional investigations on the germination capacity of conventional rapeseed and maize seed after ingestion by fallow deer and faecal excretion (endozoochory) were performed to draw conclusions regarding a potential spreading of germinable GM crop seed by deer. Germination tests revealed that germinable rapeseed kernels were detectable in faeces; in contrast, no intact maize seeds were found in faeces.

Keywords Genetically modified plants · Bt-maize MON810 $\cdot$ Bt176 $\cdot$ Wildlife

\section{Introduction}

In 1983, the first foreign gene was successfully inserted into a plant by genetic modification; in 2004, 19.3 million ha genetically modified (GM) maize plus 4.3 million ha transgenic rapeseed were planted worldwide (James 2004). The GM insect resistant maize and rapeseed variants have been modified to express the Cryl $\mathrm{Ab}$ protein originating from naturally occurring soil bacterium Bacillus thurin- 
giensis (Bt; Champolivier et al. 1999), targeting the pest insect Ostrinia nubilalis (Höfte and Whitely 1989).

Since the release of GM plants into the feed market, investigations about the effect and the digestive fate of recombinant DNA and proteins of genetically modified crop on domesticated animals, e.g. cattle, poultry and pigs, were carried out (Chowdhury et al. 2003a; Jennings et al. 2003; Phipps et al. 2003). Studies conducted with cows have illustrated that plant-derived and recombinant DNA and protein are degraded throughout the digestive tract (Chowdhury et al. 2004; Einspanier et al. 2004; Lutz et al. 2005). However, no or little information is available about wildlife feeding on GM plants. Fallow deer (Dama dama) feed on maize and rapeseed and is therefore a suitable model species for feeding experiments dealing with wild ruminants.

Originally, fallow deer is native to the Mediterranean region and parts of the Middle East. Until today, they were introduced widely in Europe, in parts of North and South America and in New Zealand for use in extensive and intensive farming operations for stocking of parks and in some regions as introduced game (Chapman 1993). Fallow deer prefer areas of mixed or deciduous woodland and grassy open spaces with shrubby undergrowth for shelter and feeding. Their diet varies seasonally. In summer, deer feed mainly on weeds and herbs but also browse on the foliage of trees and bushes. In autumn and winter, fallow deer eat nuts, berries, strips of bark, dead leaves, holly and fungi (Chapman and Chapman 1975). European farmers reporting a frequent deer presence on their land claimed that fallow deer caused damage such as grazing and flattening of crops (Mayle 1999). Fields of cereals, grasslands and rapeseed were used in the spring, while root crops are important in autumn and winter. Therefore, a dispersal of recombinant DNA and germinable GM seeds onto fields planted with isogenic plants and surrounding biotopes by wildlife cannot be excluded, and a scientific assessment of the dispersal of GM crops by wild ruminants is needed. This study aimed to tackle these topics, performing feeding experiments with fallow deer as an example for wild ruminants. It is assumed that the results of this study can be transferred to other wild ruminant taxa like Cervinae, Caprinae and Antilopinae. This study will help to estimate the general likelihood of distributing transgenic crop material by wild ruminants in Europe.

\section{Materials and methods}

To investigate, if germinable seeds of GM crops could be spread by deer, specific maize and rapeseed species, tested for their germination capacity, were used in a set of two distinct animal experiments after which animals were slaughtered, and specific characteristics in GIT contents and animal tissues were assessed. Additionally, it was studied whether intact and germinable seeds of maize and rapeseed passed the GI tract of fallow deer.

Experimental animals

Two feeding experiments with fallow deer were carried out. The first experiment consisted of 11 animals; the second experiment consisted of six animals. The live weights of the animals were between 45 and $55 \mathrm{~kg}$. The animals were kept as groups in an enclosed area of approximately $1.500 \mathrm{~m}^{2}$ per animal. The first experiment was performed in autumn/ winter (October-December) and the second in springtime (April-May).

Animal diets

Isogenic (Antares) and GM (Navares, event 176) maize (Syngenta International AG, Basel, Switzerland) as well as the isogenic and transgenic maize breeding lines, DKC3421 and DKC3421-YG (Monsanto, St. Louis), were planted and grown on experimental fields of the Bavarian State Research Center for Agriculture.

Navares (event 176) contains two copies of a synthetic truncated $c r y 1 A b$ gene under the regulation of a promoter derived from the maize phosphoenolpyruvate carboxylase gene and of a promoter from a maize calcium-dependent protein kinase gene. DKC3421-YG (event MON810) contains one copy of the $c r y l A b$ gene under regulation of the cauliflower mosaic virus promoter. Event 176-expressed full-length $\mathrm{Cry} 1 \mathrm{Ab}$ protein has a molecular weight of approximately $65 \mathrm{kDa}$; the immunoactive full-length Cry1 Ab protein in MON810 has a molecular weight of approximately $91 \mathrm{kDa}$.

Conventional rapeseed was commercially obtained and added in the second experiment to investigate endozoochory. In both experiments, water and feed were available ad libitum. Feed was prepared by mixing chopped maize, whole maize and rapeseed kernels and salt. The feed mixture was weighed and provided to the entire group of animals three times per week. No additional feed was provided, but the animals were also grazing weeds and herbs. The average daily feed intake per animal, determined by backweighing the remaining feed, was approximately $1.0 \mathrm{~kg}$ of fresh maize, $0.5 \mathrm{~kg}$ of maize kernels and $0.1 \mathrm{~kg}$ of rapeseed.

\section{Feeding trials}

Two feeding experiments with fallow deer were carried out. The first experiment consisted of six animals fed with isogenic (Antares) and five animals fed with GM (Navares) maize. In the second experiment, six fallow deer were either fed with isogenic (3 animals) or GM (3 animals) 
maize and maize seeds (DKC3421, DKC3421-YG), respectively. The animals were adapted to the diet for 1 week. The recorded feeding and sampling experiment started after the adaptation phase and was performed for $4-5$ weeks. In the second experiment, conventional rapeseed was added to investigate endozoochory of small seeds. Therefore, faeces were collected to separate maize kernels and rapeseed.

\section{Sampling procedures}

\section{Faeces}

All faeces from fallow deer were collected on a daily basis, subsequently pooled, and results were expressed as average values per group. The faeces were screened for the presence of intact grains by washing them over a sieve; another sample was frozen in liquid nitrogen for analytical purposes. At the end of the feeding studies, two of the pooled samples per experimental week, i.e. a total of approximately eight to ten samples per experimental trial, were analysed using PCR and enzyme-linked immunosorbent assay (ELISA) techniques. At the end of both experiments, the animals were slaughtered. The time lag between the last feeding and slaughter was approximately $24 \mathrm{~h}$.

\section{Gastrointestinal samples}

After slaughter, the GI contents were scanned to find intact seeds. The rumen was opened, and samples for analytical purposes were taken. The rumen content was visually checked for intact maize kernels. This procedure was repeated for all other parts of the GI tract. Pellets found in the colon and rectum contents were manually broken up and visually checked. Immediately before germination tests, isolated seeds were cleaned with water and dried.

Samples from all GI contents and visceral tissues were collected for DNA and protein analysis. Therefore, all GI segments were sequentially opened, and both the content as well as the gut epithelial tissue was taken in duplicates from every single animal. Sampling comprised the rumen, abomasum, jejunum, caecum, colon, rectum as well as liver, kidney, spleen, lymph nodes and muscles. GI contents and visceral tissues were snap-frozen in liquid nitrogen and stored at $-80^{\circ} \mathrm{C}$ until further analyses. Every single tissue and GI content sample of any animal has been subjected to DNA and protein analysis.

To exclude the possibility of contamination of the isogenic diet with recombinant material during the feeding studies, feed samples were subjected to DNA extraction and analysed for the crylAb gene using PCR techniques.

All feeding experiments were performed according to the guidelines for animal welfare of the Technical University Munich.

\section{DNA analysis}

Samples (200 mg wet sample) were ground using the FastPrep-System (BIO101, Carlsbad) and finally dissolved in 1-ml TriFast (Peqlab, Erlangen, Germany). DNA was extracted with phenol/chloroform and precipitated with ethanol. DNA purification was accomplished using the Nucleo Spin Plant Kit (Macherey-Nagel GmbH \& Co. KG, Düren, Germany) according to the manufacturer's instructions.

Oligonucleotide primers used for PCR amplification of the $c r y 1 A b$, zein and $r b c$ (ribulose-1,5-bisphosphate carboxylase/oxygenase, rubisco) gene fragments were designed referring to GenBank Accession no. I41419 (crylAb gene from patent US 5625136), no. U25674 (Zea mays zein gene) and no. X86563 (Zea mays chloroplast genome), respectively. A $18 S$ ribosomal DNA fragment was used as reference gene. Primer sequences are listed in Table 1.

All amplification reactions were carried out on a gradient thermocycler (Biometra, Göttingen, Germany). The reaction volume consisted of $150 \mathrm{ng}$ DNA, 2× PCR Master Mix containing 0.625 units of Taq polymerase (Promega, Mannheim, Germany) and $0.6 \mu \mathrm{M}$ primer (Metabion, Martinsried, Germany). Cycling conditions are listed in Table 2. Each amplification reaction was separated on a $1.8 \%$ agarose gel, stained with ethidium bromide, visualised and digitised using a video documentation system (Vilber Lourmat, Marne-la-Vallée Cedex 1, France). To verify the amplification results, amplicons were isolated and commercially sequenced (MediGenomix, München, Germany).

For PCR analyses of the rbc/zein/18S gene fragments, buffer and $\mathrm{H}_{2} \mathrm{O}$ were used as negative controls. For $c r y 1 A b$ gene analyses, isogenic maize and samples of animals fed with isogenic maize served as negative controls. All samples were analysed in duplicates.

\section{CrylAb protein analysis}

Estimation of the Cry $1 \mathrm{Ab}$ protein was carried out using a commercially available ELISA kit according to the manufacturer's instructions (Agdia, Elkhard). A standard curve with concentrations of $0.015,0.03,0.06,0.125,0.25,0.5$, 1.0 and $1.6 \mathrm{ng} / \mathrm{ml}$ was prepared using the control protein provided by the supplier. The results were expressed as nanogram Cry $1 \mathrm{Ab}$ protein per gram wet sample. All samples were measured in duplicates.

To determine the fragment size of the Cry1 Ab protein, an immunoblotting technique as described previously was applied (Lutz et al. 2005; Wiedemann et al. 2006). The samples were prepared the same way as for the ELISA technique and were then loaded onto sodium dodecyl sulfate-polyacrylamide gel electrophoresis on a 4-12\% gradient Bis-Tris gel (NuPage, Invitrogen $\mathrm{GmbH}$, Karlsruhe, Germany). After separation and transfer onto a nitro- 
Table 1 Oligonucleotide sequences for PCR analysis

\begin{tabular}{|c|c|c|}
\hline Target gene & Fragment size (bp) & Primer sequences \\
\hline \multirow[t]{10}{*}{ crylAb } & \multirow[t]{2}{*}{206} & 5'-CCT GGA GAA CTT CGA CGG TA-3' \\
\hline & & 5'-TCG TGC CGT AGA GAG GAA AG-3' \\
\hline & \multirow[t]{2}{*}{244} & 5'-CGT GCA GAA CTA CCA GGT GC-3' \\
\hline & & 5'-GGT TGT ACC TGA TCC AGT CG-3' \\
\hline & \multirow[t]{2}{*}{382} & 5'-CCT GAC CAA GAG CAC CAA CC-3' \\
\hline & & 5'-CGA TGC GGT CGA TGT ACA CC-3' \\
\hline & \multirow[t]{2}{*}{727} & 5'-ACG AGT GCA TCC CCT ACA AC-3' \\
\hline & & 5'-TAG TTG GGG AAC AGG CTC AC-3' \\
\hline & \multirow[t]{2}{*}{1,423} & 5'-ACG AGT GCA TCC CCT ACA AC-3' \\
\hline & & 5'-AGG TTG GTG CTC TTG GTC AG-3' \\
\hline \multirow[t]{10}{*}{$r b c$} & \multirow[t]{2}{*}{173} & 5'-AGC TAA TCG TGT GGC TTT AGA AGC C-3' \\
\hline & & 5'-TGG TAT CCA TCG CTT TGA AAC CA-3' \\
\hline & \multirow[t]{2}{*}{430} & 5'-AGG TAA GTT AGA AGG GGA ACG C-3' \\
\hline & & 5'-TGG TAT CCA TCG CTT TGA AAC CA-3' \\
\hline & \multirow[t]{2}{*}{896} & 5'-AGG TAA GTT AGA AGG GGA ACG C-3' \\
\hline & & 5'-TGT ATG TCC CAG AAT AGG TCC C-3' \\
\hline & \multirow[t]{2}{*}{1,197} & 5'-GGC CTA CTT CTT CAC ATT CAC C-3' \\
\hline & & 5'-CAT TCT CAT CGC CTT TCT ATC C-3' \\
\hline & \multirow[t]{2}{*}{1,753} & 5'-GGC CTA CTT CTT CAC ATT CAC C-3' \\
\hline & & 5'-AAA CTC GCT ATA GTC GGC TAG G-3' \\
\hline \multirow[t]{2}{*}{ zein } & \multirow[t]{2}{*}{329} & 5'-TGC TTG CAT TGT TCG CTC TCC TAG-3' \\
\hline & & 5'-GTC GCA GTG ACA TTG TGG CAT-3' \\
\hline \multirow[t]{4}{*}{$18 S$} & \multirow[t]{2}{*}{218} & 5'-AAG TCT TTG GGT TCC GGG-3' \\
\hline & & 5'-GGA CAT CTA AGG GCA TCA CA-3' \\
\hline & \multirow[t]{2}{*}{365} & 5'-AAG TCT TTG GGT TCC GGG-3' \\
\hline & & 5'-GGA CAT CTA AGG GCA TCA CA-3' \\
\hline
\end{tabular}

cellulose membrane, Cry1 Ab protein was detected using a polyclonal rabbit anti-Cry $1 \mathrm{Ab} / 1 \mathrm{Ac}$ antibody (final concentration $5 \mathrm{\mu g} / \mathrm{ml}$; Agdia, $60 \mathrm{~min}$ ) followed by a secondary antibody solution (biotinylated anti-rabbit $\mathrm{IgG}$ in casein solution; final concentration, $1.5 \mu \mathrm{g} / \mathrm{ml}$, $30 \mathrm{~min}$ ). For signal amplification, membranes were incubated for $10 \mathrm{~min}$ in Vectastain ABC-AmP Reagent (Vector Laboratories, Burlingame). Isogenic maize served as negative control, and $\mathrm{Cry} 1 \mathrm{Ab} / 1 \mathrm{Ac}$ protein included in the ELISA kit was used as positive control. To exclude any cross-reactions, e.g. with animal or intestinal bacteria proteins, samples of animals fed with isogenic maize were used as controls.

\section{Germination tests for maize seeds and rapeseed}

Before the feeding experiments, the germination capacity of maize and rapeseed were examined under optimal conditions

Table 2 Cycling conditions for PCR analysis

\begin{tabular}{|c|c|c|c|c|c|}
\hline Target gene & Fragment size (bp) & Denaturation & Amplification steps & Cycles & Final extension \\
\hline \multirow[t]{5}{*}{ crylAb } & 206 & $94^{\circ} \mathrm{C}, 5 \mathrm{~min}$ & $94^{\circ} \mathrm{C} 30 \mathrm{~s} ; 60^{\circ} \mathrm{C} 30 \mathrm{~s} ; 72^{\circ} \mathrm{C} 30 \mathrm{~s}$ & 40 & $72^{\circ} \mathrm{C}, 5 \mathrm{~min}$ \\
\hline & 244 & $94^{\circ} \mathrm{C}, 3 \mathrm{~min}$ & $94^{\circ} \mathrm{C} 30 \mathrm{~s} ; 60^{\circ} \mathrm{C} 30 \mathrm{~s} ; 72^{\circ} \mathrm{C} 30 \mathrm{~s}$ & 35 & $72^{\circ} \mathrm{C}, 2 \mathrm{~min}$ \\
\hline & 382 & $94^{\circ} \mathrm{C}, 3 \mathrm{~min}$ & $94^{\circ} \mathrm{C} 30 \mathrm{~s} ; 61^{\circ} \mathrm{C} 30 \mathrm{~s} ; 72^{\circ} \mathrm{C} 30 \mathrm{~s}$ & 40 & $72^{\circ} \mathrm{C}, 3 \mathrm{~min}$ \\
\hline & 727 & $94^{\circ} \mathrm{C}, 5 \mathrm{~min}$ & $94^{\circ} \mathrm{C} 30 \mathrm{~s} ; 56^{\circ} \mathrm{C} 30 \mathrm{~s} ; 72^{\circ} \mathrm{C} 30 \mathrm{~s}$ & 40 & $72^{\circ} \mathrm{C}, 5 \mathrm{~min}$ \\
\hline & 1,423 & $94^{\circ} \mathrm{C}, 5 \mathrm{~min}$ & $94^{\circ} \mathrm{C} 45 \mathrm{~s} ; 56^{\circ} \mathrm{C} 45 \mathrm{~s} ; 72^{\circ} \mathrm{C} 45 \mathrm{~s}$ & 40 & $72^{\circ} \mathrm{C}, 5 \mathrm{~min}$ \\
\hline \multirow[t]{5}{*}{$R b c$} & 173 & $94^{\circ} \mathrm{C}, 3 \mathrm{~min}$ & $94^{\circ} \mathrm{C} 30 \mathrm{~s} ; 60^{\circ} \mathrm{C} 30 \mathrm{~s} ; 72^{\circ} \mathrm{C} 30 \mathrm{~s}$ & 35 & $72^{\circ} \mathrm{C}, 2 \mathrm{~min}$ \\
\hline & 430 & $94^{\circ} \mathrm{C}, 3 \mathrm{~min}$ & $94^{\circ} \mathrm{C} 30 \mathrm{~s} ; 60^{\circ} \mathrm{C} 30 \mathrm{~s} ; 72^{\circ} \mathrm{C} 30 \mathrm{~s}$ & 40 & $72^{\circ} \mathrm{C}, 3 \mathrm{~min}$ \\
\hline & 896 & $94^{\circ} \mathrm{C}, 5 \mathrm{~min}$ & $94^{\circ} \mathrm{C} 45 \mathrm{~s} ; 58^{\circ} \mathrm{C} 45 \mathrm{~s} ; 72^{\circ} \mathrm{C} 45 \mathrm{~s}$ & 40 & $72^{\circ} \mathrm{C}, 5 \mathrm{~min}$ \\
\hline & 1,197 & $94^{\circ} \mathrm{C}, 5 \mathrm{~min}$ & $94^{\circ} \mathrm{C} 45 \mathrm{~s} ; 58^{\circ} \mathrm{C} 45 \mathrm{~s} ; 72^{\circ} \mathrm{C} 45 \mathrm{~s}$ & 40 & $72^{\circ} \mathrm{C}, 5 \mathrm{~min}$ \\
\hline & 1,753 & $94^{\circ} \mathrm{C}, 5 \mathrm{~min}$ & $94^{\circ} \mathrm{C} 45 \mathrm{~s} ; 58^{\circ} \mathrm{C} 45 \mathrm{~s} ; 72^{\circ} \mathrm{C} 45 \mathrm{~s}$ & 40 & $72^{\circ} \mathrm{C}, 5 \mathrm{~min}$ \\
\hline Zein & 329 & $94^{\circ} \mathrm{C}, 3 \mathrm{~min}$ & $94^{\circ} \mathrm{C} 30 \mathrm{~s} ; 61^{\circ} \mathrm{C} 30 \mathrm{~s} ; 72^{\circ} \mathrm{C} 30 \mathrm{~s}$ & 40 & $72^{\circ} \mathrm{C}, 2 \mathrm{~min}$ \\
\hline \multirow[t]{2}{*}{$18 S$} & 218 & $94^{\circ} \mathrm{C}, 2 \mathrm{~min}$ & $94^{\circ} \mathrm{C} 30 \mathrm{~s} ; 60^{\circ} \mathrm{C} 30 \mathrm{~s} ; 72^{\circ} \mathrm{C} 30 \mathrm{~s}$ & 30 & $72^{\circ} \mathrm{C}, 2 \mathrm{~min}$ \\
\hline & 365 & $94^{\circ} \mathrm{C}, 3 \mathrm{~min}$ & $94^{\circ} \mathrm{C} 30 \mathrm{~s} ; 60^{\circ} \mathrm{C} 30 \mathrm{~s} ; 72^{\circ} \mathrm{C} 30 \mathrm{~s}$ & 35 & $72^{\circ} \mathrm{C}, 3 \mathrm{~min}$ \\
\hline
\end{tabular}


according to the current international rules for seed testing (International Seed Testing Association 2004; ISTA, Switzerland). The tests of maize, which were performed with $8 \times$ 50-pure seeds for each cultivar, were carried out in sand at $20^{\circ} \mathrm{C}$ and $8 \mathrm{~h}$ daylight in a growth chamber. The tests of rapeseed with $8 \times 50$-pure seeds each were carried out on top of paper in the Jacobsen germination apparatus at alternating temperatures, $8 \mathrm{~h}$ daylight $\left(30^{\circ} \mathrm{C}\right)$ and $16 \mathrm{~h}$ darkness $\left(20^{\circ} \mathrm{C}\right)$. Seedlings and seeds of both species were evaluated after 7 days according ISTA rules and classified as normal, abnormal seedlings, fresh and dead seeds, respectively.

\section{Results}

As both feeding trials addressed the detectability of the $c r y 1 A b$ gene and protein after ingestion and digestion in fallow deer, the results for recombinant DNA and protein analyses of both feeding experiments are presented together. The germination experiments have only been performed in experiment 2, which implies that these results are solely based on one experimental trial.

\section{DNA analysis}

Amplicons (173 bp) of the highly abundant endogenous chloroplast-specific $r b c$ gene were detectable in GI contents and visceral tissues of fallow deer fed isogenic or GM maize (Fig. 1a).

$R b c$ gene fragments of $430 \mathrm{bp}$ were found in GI contents, and fragment sizes of 896 bp were detectable in rumen content (Fig. 1a). No higher sized $r b c$ gene fragments were found in any fallow deer sample; maize samples were used as positive controls and resulted in the detection of larger DNA fragments. Maize-specific zein gene fragments with sizes of $329 \mathrm{bp}$ were detectable in GI contents and occasionally in visceral tissues (Fig. 1b). No fragments of the crylAb gene in sizes of 204, 244, 382, 727 and $1,423 \mathrm{bp}$ were found (exemplified for the $244 \mathrm{bp}$ crylAb fragment in Fig. 1b). Initial PCR analyses in our laboratories revealed that in both GM maize varieties (Navares and MON810), the respective fragments could be detected in the raw materials used for feeding (data not shown). The number of samples subjected to PCR analysis, the results and the detection rates for the $r b c$, zein, $18 S$ and $c r y 1 A b$ gene fragments in isogenic and transgenic samples are summarised in Table 3.

\section{Cry1 Ab protein analysis}

Cry $1 \mathrm{Ab}$ protein was tested by ELISA and immunoblotting techniques. Initial ELISA assays in our laboratories
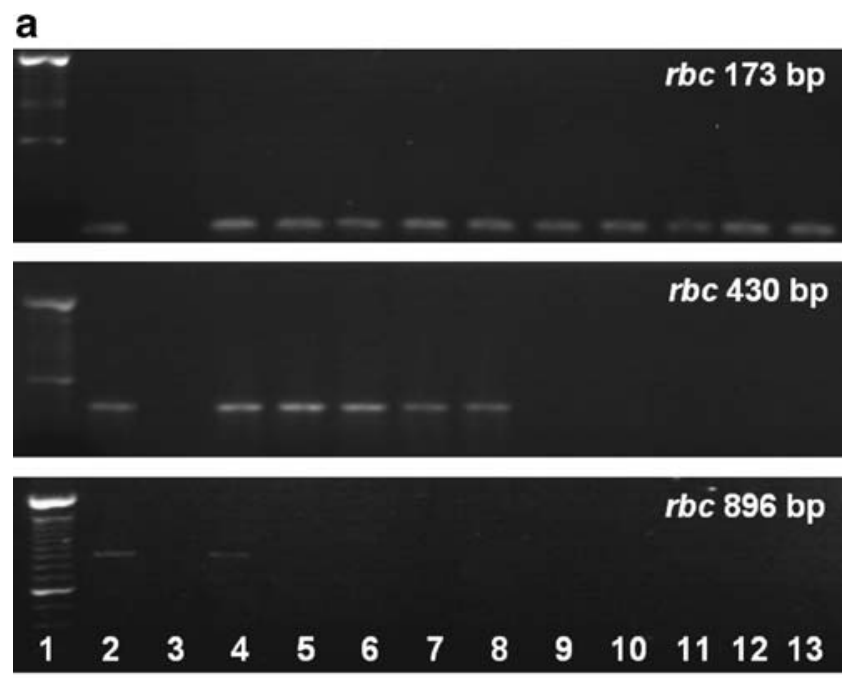

b
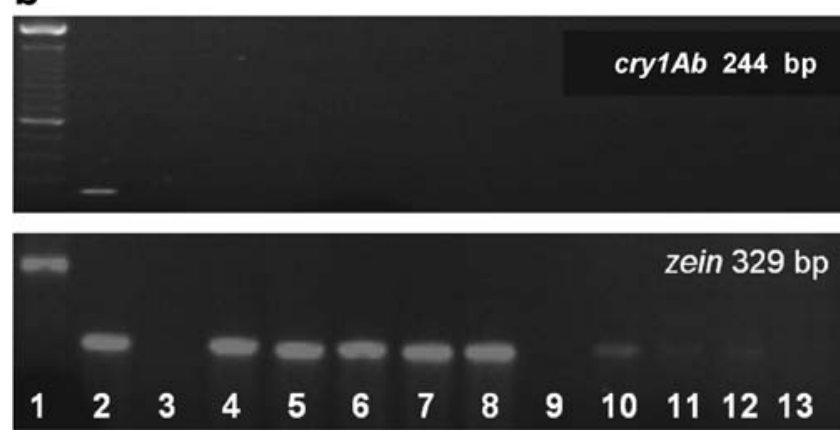

Fig. 1 Agarose gel electrophoresis of PCR products in samples of fallow deer fed isogenic or GM maize. a $r b c$ gene; $\mathbf{b} c r y l A b$ and zein gene: $1=$ DNA standard (100-bp DNA ladder), $2=$ positive control, $3=$ negative control, $4=$ rumen content, $5=$ abomasum content, $6=$ jejunum content, $7=$ caecum content, $8=$ colon content, $9=$ spleen, $10=$ kidney, $11=$ lymphatic node, $12=$ liver and $13=$ muscle

revealed that protein extracts made from both GM varieties that were used for feeding (Navares and MON810) yielded the respective positive signals for Cry1 Ab protein (data not shown). By ELISA, a total of approximately 170 tissues or GI content samples of GM-fed animals have been screened. Immunoactive $\mathrm{Cry} 1 \mathrm{Ab}$ protein was not detectable in any tissue or GI content of fallow deer fed with GM maize neither by ELISA nor by immunoblotting technique. In contrast to the positive control (Cry $1 \mathrm{Ab} / 1 \mathrm{Ac}$ protein, included in the ELISA kit) and leave samples of GM maize (Navares), no sample of isogenic maize and animal origin showed a Cryl Ab protein specific band with the immunoblotting assay (Fig. 2).

\section{Germination tests}

Before the second feeding experiment, germination tests with isogenic (DKC3421), GM (DKC3421-YG) maize seeds and rapeseed were performed. These assays revealed a germination of $87 \pm 1.9 \%$ normal seedlings, $9 \pm 1.5 \%$ abnormal seedlings and $4 \pm 1.2 \%$ dead seeds for the isogenic 
Table 3 Summary of DNA analyses in gastrointestinal contents and tissues of fallow deer fed isogenic or transgenic maize

\begin{tabular}{|c|c|c|c|c|c|c|c|c|}
\hline \multirow{3}{*}{$\frac{\text { Target gene }}{\text { Fragment size (bp) }}$} & \multirow{2}{*}{\multicolumn{2}{|c|}{$\frac{18 S}{365}$}} & \multirow{2}{*}{\multicolumn{2}{|c|}{$\frac{r b c}{173}$}} & \multirow{2}{*}{\multicolumn{2}{|c|}{$\frac{z e i n}{329}$}} & \multirow{2}{*}{\multicolumn{2}{|c|}{$\frac{c r y 1 A b}{206}$}} \\
\hline & & & & & & & & \\
\hline & $\begin{array}{l}\text { Isogenic } \\
\text { maize }\end{array}$ & $\begin{array}{l}\text { Transgenic } \\
\text { maize }\end{array}$ & $\begin{array}{l}\text { Isogenic } \\
\text { maize }\end{array}$ & $\begin{array}{l}\text { Transgenic } \\
\text { maize }\end{array}$ & Isogenic maize & $\begin{array}{l}\text { Transgenic } \\
\text { maize }\end{array}$ & $\begin{array}{l}\text { Isogenic } \\
\text { maize }\end{array}$ & $\begin{array}{l}\text { Transgenic } \\
\text { maize }\end{array}$ \\
\hline Rumen content & $100 \%(6 / 6)$ & $100 \%(6 / 6)$ & $66.7 \%(4 / 6)$ & $62.5 \%(5 / 8)$ & $66.7 \%(4 / 6)$ & $50 \%(3 / 6)$ & $0 \%(0 / 6)$ & $0 \%(0 / 6)$ \\
\hline $\begin{array}{l}\text { Abomasum } \\
\text { content }\end{array}$ & $66.7 \%(4 / 6)$ & $83.3 \%(5 / 6)$ & $55.6 \%(5 / 9)$ & $50 \%(4 / 8)$ & $0 \%(0 / 6)$ & $16.7 \%(1 / 6)$ & $0 \%(0 / 6)$ & $0 \%(0 / 6)$ \\
\hline Jejunum content & $33.3 \%(2 / 6)$ & $66.7 \%(4 / 6)$ & $0 \%(0 / 9)$ & $0 \%(0 / 8)$ & $8.3 \%(1 / 12)$ & $0 \%(0 / 6)$ & $0 \%(0 / 6)$ & $0 \%(0 / 6)$ \\
\hline Caecum content & $83.3 \%(5 / 6)$ & $83.3 \%(5 / 6)$ & $0 \%(0 / 9)$ & $12.5 \%(1 / 8)$ & $0 \%(0 / 12)$ & $0 \%(0 / 6)$ & $0 \%(0 / 6)$ & $0 \%(0 / 6)$ \\
\hline Colon content & $83.3 \%(5 / 6)$ & $100 \%(6 / 6)$ & $16.7 \%(1 / 6)$ & $0 \%(0 / 6)$ & $16.7 \%(2 / 12)$ & $16.7 \%(1 / 6)$ & $0 \%(0 / 6)$ & $0 \%(0 / 6)$ \\
\hline Spleen & $66.7 \%(4 / 6)$ & $83.3 \%(5 / 6)$ & $16.7 \%(1 / 6)$ & $33.3 \%(2 / 6)$ & $33.3 \%(4 / 12)$ & $33.3 \%(2 / 6)$ & $0 \%(0 / 6)$ & $0 \%(0 / 6)$ \\
\hline Kidney & $83.3 \%(5 / 6)$ & $83.3 \%(5 / 6)$ & $33.3 \%(2 / 6)$ & $50 \%(3 / 6)$ & $41.7 \%(5 / 12)$ & $50 \%(3 / 6)$ & $0 \%(0 / 6)$ & $0 \%(0 / 6)$ \\
\hline Lymph nodes & $100 \%(6 / 6)$ & $100 \%(6 / 6)$ & $50 \%(3 / 6)$ & $16.7 \%(1 / 6)$ & $50 \%(3 / 6)$ & $33.3 \%(2 / 6)$ & $0 \%(0 / 6)$ & $0 \%(0 / 6)$ \\
\hline Liver & $100 \%(6 / 6)$ & $100 \%(6 / 6)$ & $50 \%(3 / 6)$ & $50 \%(3 / 6)$ & $33.3 \%(2 / 6)$ & $33.3 \%(2 / 6)$ & $0 \%(0 / 6)$ & $0 \%(0 / 6)$ \\
\hline Muscle & $83.3 \%(5 / 6)$ & $83.3 \%(5 / 6)$ & $50 \%(3 / 6)$ & $16.7 \%(1 / 6)$ & $33.3 \%(2 / 6)$ & $50 \%(3 / 6)$ & $0 \%(0 / 6)$ & $0 \%(0 / 6)$ \\
\hline Control (maize) & $100 \%(6 / 6)$ & $100 \%(6 / 6)$ & $100 \%(9 / 9)$ & $100 \%(8 / 8)$ & $100 \%(6 / 6)$ & $100 \%(6 / 6)$ & $0 \%(0 / 6)$ & $100 \%(6 / 6)$ \\
\hline
\end{tabular}

variety. For the recombinant breed, $85 \pm 1.4 \%$ normal seedlings, $9 \pm 1.8 \%$ abnormal seedlings and $6 \pm 1.2 \%$ dead seeds were found. For rapeseed, $93 \pm 1.9 \%$ normal seedlings, $4 \pm$ $1.4 \%$ abnormal seedlings and $3 \pm 1.4 \%$ dead seeds were detected. The classification was carried out according to ISTA rules (International Seed Testing Association 2004).

A total of 81 intact isogenic rapeseed kernels were isolated from faeces collected from six animals throughout the entire experimental period (experiment 2; six animals in total, all being fed rapeseed plus either isogenic maize [three animals] or transgenic maize [three animals]; see "Materials and methods"). The subsequently performed germination test resulted in $14 \%(n=11)$ normal seedlings, $4 \%(n=3)$ abnormal seedlings and $82 \%(n=67)$ dead seeds. No intact maize seeds were detectable in faeces and rectum content obtained from all animals throughout the entire feeding experiment. Macroscopically identifiable particles of maize grains were present in rectum content or faeces. They were classified as non-germinable and were not relevant with regard to the dispersal of GMO maize.

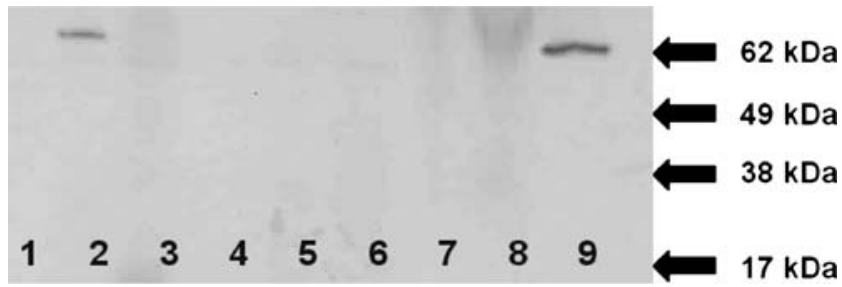

Fig. 2 Immunoblotting of gastrointestinal contents and tissues from fallow deer fed transgenic maize. $l=$ isogenic maize leaves (Antares); $2=$ transgenic maize leaves (Navares); $3=$ rumen content; $4=$ jejunum content; $5=$ caecum content; $6=$ colon content; $7=$ spleen; $8=$ lymphatic node; and 9=positive control (Cry1Ab/1Ac Protein, Agdia). Arrows indicate the molecular weight standard (SeeBlue Plus2, Invitrogen $\mathrm{GmbH})$

\section{Discussion}

This study was accomplished to investigate the fate of plant-specific and recombinant DNA and of the recombinant $\mathrm{Cry} 1 \mathrm{Ab}$ protein from GM maize on fallow deer and to investigate the dispersal of germinable rapeseed and maize seeds (endozoochory).

Regarding the DNA-analysis, only short chloroplastspecific $r b c$ and zein gene fragments, derived from forage plants, with sizes of 173 and $329 \mathrm{bp}$, respectively, were found in GI contents and occasionally in the liver, kidney, spleen, muscle and lymphatic nodes of fallow deer. Larger plant gene fragment sizes ( $>400 \mathrm{bp}$ ) were only found in GI contents. No cryl $A b$ gene fragments (244 bp) were detected in any fallow deer sample. The present results suggest that DNA is not entirely degraded during digestion, and GIT passage in fallow deer and small DNA fragments could pass the visceral tissues probably through $\mathrm{M}$ cells on Peyer's patches. The transfer of DNA fragments to viscera and concomitantly their detection seems to depend on the fragment size and the number of gene copies. Our results are similar to findings in feeding studies with calves (Chowdhury et al. 2004) where small DNA fragments (226 bp) of the rubisco gene were found in liver, spleen, kidney, muscle and lymph nodes. Chowdhury et al. (2004) detected 242-bp fragments of the maize-specific zein gene in GI contents of calves fed with transgenic (Bt11) or non$\mathrm{Bt}$ maize. However, neither in studies by Einspanier et al. (2001) nor in investigations by Chowdhury et al. (2004) were $c r y l A b$ gene fragments detected in ruminant tissue samples, suggesting that the copy number is the main limiting factor in the traceability of the transgenic component. In this context, the resemblance between domestic ruminants (calves, cattle) and wildlife ruminants (fallow 
deer) during DNA digestion is obvious. Further investigations in our laboratories regarding the degradability of DNA in wild pigs and pheasants (data unpublished) revealed similar results as feeding studies with chicken (Einspanier et al. 2001) and domestic pigs (Chowdhury et al. 2004). Taken together, these studies suggest that there are differences in the degradation processes because of distinct digestion systems of monogastric and polygastric species. Monogastric animals (like pigs) and polygastric avian species (like poultry) digest food mainly enzymatically before or after mechanical disruption. In these species, highly abundant plant DNA fragments were found in various tissues, organs and in blood. In ruminants (like cattle), which are able to break down cellulose microbially, endogenous plant DNA fragments were only found in the contents of the GI tract and in the blood but not in any organs or tissue tested. To date, transgenic DNA fragments were not detected beyond the barrier of the GI tract in any species (results are summarised in Flachowsky et al. 2005). When comparing data of DNA analyses between domestic animals and wildlife with similar digestion systems investigated in this context, only minor variations are found.

When specifically tracing the fate of the recombinant protein using the sensitive ELISA technique, no positive signals of the Cry $1 \mathrm{Ab}$ protein were detected in samples from GI contents and tissues of fallow deer. The immunoblotting assay yielded no bands for the Cry $1 \mathrm{Ab}$ protein in deer samples except for the positive control and GM maize leaves. In previous feeding studies with ruminants, the fate of recombinant $\mathrm{Cry} 1 \mathrm{Ab}$ protein in the bovine GI tract was likewise monitored using ELISA and immunoblotting technique (Lutz et al. 2005; Wiedemann et al. 2006). In situ studies with cows showed that the full-length Cry $1 \mathrm{Ab}$ protein could be detected in the bovine rumen up to $8 \mathrm{~h}$ after feeding (Wiedemann et al. 2006). Thereafter, only degraded Cry $1 \mathrm{Ab}$ protein fragments of 17 and $34 \mathrm{kDa}$ were found as shown previously also in bovine intestine samples (Lutz et al. 2005). Chowdhury et al. (2003a, b) found the full-length Cry $1 \mathrm{Ab}$ protein within Bt11 maize in different parts of the GI tract of calves with ELISA and immunoblotting technique and suggested that only a trace amount of Cry $1 \mathrm{Ab}$ protein survives the passage through the GI tract but is not transferred to liver, spleen, kidney, lymph nodes or muscles.

The inability to detect Cry1 Ab protein in rumen of fallow deer may be additionally caused by the fact that the animals did not only ingest the maize as their diet but were also grazing weeds and herbs. However, the results of this study suggest that no or only minute amounts of bioactive Cry $1 \mathrm{Ab}$ protein will be present in the GI tract of fallow deer. Any potential impact of such low amounts of the Cryl Ab protein or its fragments on mammalian intestinal cells shall not cause toxicologically relevant effects, particularly as the harmlessness of Cryl Ab is generally accepted.
Our investigations on the subject of endozoochory of germinable maize seeds and rapeseed by fallow deer revealed that excreted rapeseed were able to germinate, while no intact maize seeds were detectable in faeces and rectum content. In this context, Heinken et al. (2001, 2005; Heinken and Raudnitschka 2002) reported that fallow deer transport various diasporas (seeds and fruits) in the coats and hooves (epizoochory). In fallow deer faeces, 42 vascular plant species, among them economically valuable plants, were found (Heinken et al. 2005). Despite of finding no intact maize seeds in this study with fallow deer, it cannot be excluded that intact maize grains or rather intact plant material might be detected in other deer species such as red deer or moose as the efficacy of the mastication process might be influenced by other factors such as body size, developmental stage (juvenile vs adult), illness (e.g. diarrhea) or distinct species characteristics.

Rapeseed is known to retain its germination capacity up to 5 years, sometimes even longer. Its germination capacity will be maintained, and development of a plant could be possible if seeds were placed in favorable environmental conditions (Pekrun et al. 1998). As discussed previously, gene flow from GM canola (Brassica napus) to native relatives, such as Brassica rapa and Raphanus raphanistrum, will be a very rare event, and the acquired insect resistance would not provide the plant with enhanced fitness in comparison to the wild relatives (Steward et al. 2002).

\section{Conclusion}

$R b c, 18 S$ and zein, but no recombinant $c r y l A b$ gene fragments, were detectable in GI contents and visceral tissues of fallow deer. With regard to the Cry1 Ab protein, ELISA results suggest that the intestinal digestive enzyme activities are effective in degrading the recombinant $\mathrm{Cry} 1 \mathrm{Ab}$ protein. The possibility of an uncontrolled dispersal of germinable maize seed by fallow deer is extremely low caused by the effective mastication and digestion process. However, it cannot be excluded that intact maize grains or rather intact plant material might be detected in other deer species as the efficacy of the mastication process might be influenced by other factors such as body size, developmental stage, illness (e.g. diarrhea) or other distinct species characteristics. Uncontrolled dispersal of rapeseed could be more likely and therefore should be further taken into account when liberating GM plants with a small seedling size like rape.

Acknowledgement This study was supported by the Federal Agency for Nature Conservation (BfN grant no. 20767432). We are indebted to former and recent members of the Physiology Weihenstephan (TUM, Freising) especially to Stefanie Rief, Steffi Wiedemann and M.A. Pinzón Olejua. Furthermore, we thank the staff of the working group 
Seed Testing and Seed Research in the Institute for Crop Science and Plant Breeding (Bavarian State Research Center, Freising) and Wildlife Biology and Management Unit (TUM, Freising) for their assistance during these studies. We also thank Prof. O. Rottmann (TUM Freising) for his support.

The authors affirm that the feeding studies with fallow deer dealt within this publication comply with the current law.

\section{References}

Champolivier J, Gasquez J, Messéan A (1999) Crop management of transgenic rapeseed: risk assessment of gene flow. In: New horizons for an old crop. Proceedings of the 10th International Rapeseed Congress, Canberra, Australia

Chapman N (1993) Distribution and biology of fallow deer. In: Asher GW (ed) Proceedings of the first world forum on fallow deer farming, Mudgee, NSW, Australia, 10-13 March 1993, p 1

Chapman D, Chapman N (1975) Fallow deer: their history, distribution and biology. Terence Dalton, Lavenham, Suffolk, UK

Chowdhury EH, Kuribara H, Hino A, Sutana P, Mikami O, Shimada N, Guruge KS, Saito M Nakajima Y (2003a) Detection of corn intrinsic and recombinant DNA fragments and Cry1 $\mathrm{Ab}$ protein in the GI contents of pigs fed genetically modified corn Bt11. J Anim Sci 81:2546-2551

Chowdhury EH, Shimada N, Murata H, Mikami O, Sultana P, Miyazaki S, Yoshioka M, Yamanaka N, Hirai N, Nakajima Y (2003b) Detection of Cry1 Ab protein in GI contents but not visceral organs of genetically modified Bt11-fed calves. Vet Hum Toxicol 45:71-75

Chowdhury EH, Mikami O, Murata H, Sultana P, Shimada N, Yoshioka M, Guruge KS, Yamamoto S. Miyazaki S, Yamanaka N, Nakajima Y (2004) Fate of maize intrinsic and recombinant genes in calves fed genetically modified maize Bt11. J Food Prot 67:365-370

Einspanier R, Klotz A, Kraft J, Aulrich K, Poser R, Schwägele F, Jahreis G, Flachowsky G (2001) The fate of forage DNA in farm animals: a collaborative case study investigating cattle and chicken fed recombinant plant material. Eur Food Res Technol 212:129-134

Einspanier R, Lutz B, Rief S, Berezina O, Zverlov V, Schwarz W, Mayer J (2004) Tracing residual recombinant feed molecules during digestion and rumen bacterial diversity in cattle fed transgenic maize. Eur Food Res Technol 218:269-273
Flachowsky G, Chesson A, Aulrich K (2005) Animal nutrition with feeds from genetically modified plants. Arch Anim Nutr 59:1-40

Heinken T, Raudnitschka D (2002) Do wild ungulates contribute to the dispersal of vascular plants in central European forests by epizoochory? A case study in NE Germany. Forstwiss Cent bl 121:179-194

Heinken T, Lees R, Raudnitschka D, Runge S (2001) Epizoochorous dispersal of bryophyte stem fragments by roe deer (Capreolus capreolus) and wild boar (Sus scrofa). J Bryol 23:293-300

Heinken T, Oheimb G v, Schmidt M, Kriebitzsch W-U, Ellenberg H (2005) Schalenwild breitet Gefäßpflanzen in der mitteleuropäischen Kulturlandschaft aus-ein erster Überblick. Nat Landsch 4:141-147

Höfte H, Whitely HR (1989) Insecticidal crystal proteins of Bacillus thuringiensis. Microbiol Rev 53:242-255

International Seed Testing Association (2004) International Rules for Seed Testing. ISTA, Switzerland (ISBN 3-906549-38-0)

James C (2004) Preview: global status of commercialised biotech/GM crops. ISAAA, Ithaca, NY (ISAAA Briefs 32)

Jennings JC, Albee LD, Kolwyck DC, Suber JB, Taylor ML, Hartnell GF, Lirette RP, Glenn KC (2003) Attempts to detect transgenic and endogenous plant DNA and transgenic protein in muscle from broilers fed YieldGard Corn borer corn. Poult Sci 82:371-380

Lutz B, Wiedemann S, Einspanier R, Mayer J, Albrecht C (2005) Degradation of Cry1 Ab protein from genetically modified maize in the bovine gastrointestinal tract. J Agric Food Chem 53:1454-1456

Mayle B (1999) Domestic stock grazing to enhance woodland biodiversity. Forestry Commission Information Note 28. Forestry Commission, Edinburgh

Pekrun C, Lutman PJW, Baeumer K (1998) Research on volunteer rape. A review. Pflanzenbauwissenschaften 2:84-90

Phipps RH, Deaville ER, Maddison BC (2003) Detection of transgenic and endogenous plant DNA in rumen fluid, duodenal digesta, milk, blood and faeces of lactating dairy cows. J Dairy Sci 86:4070-4078

Steward NC Jr, Halfhill MD, Warwick S (2002) Gene flow and its consequences: Brassica napus (canola, oilseed rape) to wild relatives. In: Gene flow workshop, The Ontario State University, March 2002, pp 106-112

Wiedemann S, Lutz B, Kurtz H, Schwarz FJ, Albrecht C (2006) In situ studies on the time-dependent degradation of recombinant corn DNA and protein in the bovine rumen. J Anim Sci 84:135144 